\title{
Analisis terhadap Faktor Tingginya Angka Cerai Gugat (Studi kasus di Pengadilan Agama Polewali Tahun 2019)
}

\author{
Saifuddin, Misbayanti \\ Prodi Hukum Ekonomi Syariah, Fakultas Agama Islam, Universitas Al Asyariah Mandar \\ puddin.saifuddin.co.id
}

\begin{abstract}
Abstrak
Penelitian ini bertujuan untuk mengetahui faktor penyebab tingginya kasus peceraian gugat di Pengadilan Agama Polewali tahun 2019 dan mengetahui pertimbangan hakim dalam memutuskan perkara cerai gugat di Pengadilan Agama Polewali tahun 2019, adapun metode digunakan adalah metode lapangan (Field Research) kualitatif deskriftif, yakni penelitian dengan cara langsung terjun ke lokasi penelitian untuk memperoleh data-data yang di perlukan. Adapun sumber dari penelitian ini berasal dari data cerai gugat di Pengadilan Agama Polewali. Selanjutnya, metode pengumpulan data yang digunaka dalam metode ini adalah dokumentasi dan wawancara, lalu teknik pengelolaan data analisis data yang dilakukan dengan mengumpulkan data yang bersifat deskriftif dalam bentuk katakata dan hasil wawancara.. Hasil penelitian menunjukkan bahwa faktor penyebab tingginya cerai gugat di Pengadilan Agama Polewali tahun 2019 antara lain: 1) Perselisihan Terus Menerus sebanyak 321 perkara, 2) Meninggalkan Salah Satu Pihak sebanyak 97 perkara, 3) Ekonomi 30 perkara, 4) KDRT 16 perkara, 5) Mabuk 8 perkara, 6) Dihukum Penjara sebanyak 4 perkara, 7) Mandat 3 perkara, 8) Poligami sebanyak 3 perkara, 9) Murtad 3 perkara, 10) Judi 1 perkara, 11) Kawin Paksa sebanyak 1 perkara.
\end{abstract}

Kata Kunci:Cerai, Hukum Keluarga , Pengadilan Agama, Perkawinan

\section{I.PENDAHULUAN}

Perkawinan merupakan hal yang sakral bagi manusia yang menjalaninya, tujuan perkawinan diantaranya untuk membentuk sebuah keluarga yang harmonis yang dapat membentuk suasana bahagia menuju terwujudnya ketenangan, kenyamanan bagi suami isteri serta anggota keluarga. perkawinan adalah ikatan lahir batin antara seorang pria dan seorang wanita sebagai suami isteri dengan tujuan membentuk keluarga atau rumah tangga yang bahagia dan kekal berdasarkan Ketuhanan Yang Maha Esa. ${ }^{1}$ Tujuan dari perkawinan itu adalah bentuk suatu keluarga sakinah mawaddah warahmah, perlu diatur dengan syarat dan rukun

${ }^{1}$ Undang-Undang No. 1 Tahun 1974 tentang Perkawina Pasal 1 
tertentu, agar tujuan yang disyari'atkan perkawinan tercapai. ${ }^{2}$ Dalam sudut pandang Agama Islam perkawinan merupakan sarana yang dihalalkan bagi sepasang manusia untuk memenuhi kebutuhan biologis dalam pergaulan suami istri sekaligus bertujuan untuk memenuhi harapan agar dapat memperoleh keturunan juga sebagai sarana untuk mewujudkan rasa cinta dan kasih sayang antara suami isteri. ${ }^{3}$

Ketentuan pasal 115 Kompilasi Hukum Islam yaitu : "Perceraian hanya dapat dilakukan di depan sidang Pengadilan Agama setelah Pengadilan Agama tersebut berusaha dan tidak berhasil mendamaikan kedua belah pihak"

Berdasarkan ketentuan di atas jelaslah bahwa undang-undang perkawinan pada prinsipnya memperketat terjadinya perceraian, dimana menentukan perceraian hanya dapat dilaksanakan dihadapan sidang pengadilan, juga harus disertai alasanalasan tertentu untuk melakukan perceraian. Putusnya perkawinan itu dapat terjadi karena talak atau berdasarkan gugatan perceraian maka dari berbagi peraturan tersebut dapat di ketahui ada dua macam perceraian yaitu cerai gugat dan cerai talak. Undang-undang perkawinan membedakan antara peceraian atas kehendak suami dan dengan peceraian kehendak istri. Peceraian ataskehendak suami diseburt cerai talak dan peceraian atas kehendak istri disebut dengan cerai gugat ${ }^{4}$.

Cerai Gugat hanya berlaku bagi mereka yang beragama Islam dan diajukan oleh pihak istri. Cerai Gugat adalah istilah yang khusus digunakan dilingkungan Peradilan Agama untuk membedakan para pihak yang mengajukan cerai. Dalam perkara gugat pihak yang mengajukan adalah istri sedangkan cerai talak pihak yang mengajukan adalah suami. Putusnya perkawinan yang disebabkan karena perceraian dapat terjadi karena talak ataupun berdasarkan gugatan perceraian. ${ }^{5}$

\section{II.TINJAUAN PUSTAKA}

Perkawinan menurut istilah hukum islam sama dengan kata nikah dan kata zawaj. Nikah menurut bahasa mempunyai arti sebenarnya (haqiqat) yakni dham yang berarti menghimpit, menindih atau berkumpul. Nikah mempunyai arti kiasan

\footnotetext{
${ }^{2}$ Ahmad Rofiq, Hukum Islam Indonesia, (PT Raja Garfindo Persada, 2003), h. 70

${ }^{3}$ Sayyid Sabiq, Fiqih Sunnah Jilid VI, (Bandung:Al-Maarif, 1990), h. 7

${ }^{4}$ A. Mukti Arto, Praktek Perkara Perdata pada Pengadilan Agama, (Yogyakarta:
} Pustaka Pelajar, 1998), h. 202.

${ }^{5}$ Kompilasi Hukum Islam Pasal 114 
yakni wathaa yang berarti setubuh atau aqad yang berarti mengadakan perjanjian pernikahan. ${ }^{6}$

Berdasarkan Pasal(1) UU RI No.1 Tahun 1974 Tentang Perkawinan, Perkawinan adalah ikatan lahir dan batin antara seorang pria dengan seorang wanita sebagai suami istri dengan tujuan membentuk keluarga (rumah tangga) yang bahagia dan kekal berdasarkan Ketuhanan Yang Maha Esa. Berdasarkan Pasal (2) Kompilasi Hukum Islam (KHI), perkawinan adalah akad yang sangat kuat (mistaqan ghalizan) untuk mentaati perintah Allah dan melaksanakannya merupakan ibadah. ${ }^{7}$

Sebagai kesimpulan bahwa perkawinan adalah suatu aqad (perjanjian) antara seorang laki-laki dengan seorang perempuan dalam memenuhi kebutuhan jasmani dan rohaninya sebagai manusia. Selain itu juga merupakan suatu anjuran dari agama agar kebutuhan jasmani dan rohaninya itu tersalur dengan jalan yang halal dan suci, sehingga menghasilkan keturunan yang baik disamping mendapat tempat yang terpandang dalam masyarakat dengan berlandaskan kepada ketentuan syara' dan ketentuan-ketentuan umum yang berlaku.

\section{A. Tujuan perkawinan}

Adapun tujuan dari perkawinan adalah untuk memenuhi petunjuk agama dalam rangka mendirikan keluarga yang harmonis, sejahtera dan bahagia. ${ }^{8}$ Sedangkan menurut Imam al Ghozali sebagaimana dikutip oleh Abdul Rohman Ghozali,tujuan perkawinan adalah: ${ }^{9}$

1. Mendapatkan dan melangsungkan keturunan.

2. Memenuhi hajat manusia untuk menyalurkan syahwat dan menumpahkan kasih sayang.

3. Memenuhi panggilan agama, memelihara diri dari kejahatan dan kerusakan.

4. Menumbuhkan kesungguhan untuk bertanggung jawab menerima hak serta kewajiban dan untuk memperoleh harta kekeyaan yang halal.

5. Membangun rumah tangga untuk membentuk masyarakat yang tentram atas dasar cinta dan kasih sayang.

B. Syarat dan Rukun Perkawinan

Menurut Undang-undang bahwa untuk dapat melangsungkan

${ }^{6}$ Abd. Shomad, Hukum Islam : Penormaan Prinsip Syariah dalam Hukum Indonesia, (Jakarta, Kencana, 2010), h. 272

${ }^{7}$ Undang-Undang Republik Indonesia Nomor 1 Tahun 1974 Tentang Perkawinan dan Kompilasi Hukum Islam (Bandung: t.p, t.t), hlm. 228.

${ }^{8}$ Abdul Rahman Ghozali, Fiqh Munakaha (Jakarta: Prenada Media Group, 2003), h. 22.

${ }^{9}$ Abdul Rahman Ghozali, Fiqh Munakahat, h. 23. 
perkawinan haruslah dipenuhi syarat-syarat pokok demi sahnya suatu perkawinan antara lain :

1. Pihak-pihak calon mempelai dalam keadaan tidak kawin (pasal $27 \mathrm{BW}$ ).

2. Masing-masing pihak harus mencapai umur minimum yang ditentukan oleh undang-undang (Pasal 29 BW ).

3. Seorang wanita tidak diperbolehkan kawin lagi sebelum lewat 300 hari terhitung sejak bubarnya perkawinan ( Pasal $34 \mathrm{BW}$ ).

4. Dengan kemauan yang bebas, tidak ada paksaan ( Pasal 28 BW ).

5. Tidak ada hubungan darah atau hubungan keluarga sangat dekat antara keduanya ( Pasal 30 dan Pasal 31 BW ).

6. Antara keduanya tidak pernah melakukan overspel ( Pasal $32 \mathrm{BW}$ ).

7. Tidak melakukan perkawinan terhadap orang yang sama setelah cerai untuk yang ketiga kalinya. ${ }^{10}$

Undang-undang perkawinan mengatur syarat-syarat perkawinan dalam Bab II pasal

1. Perkawinan harus di dasarkan atas persetujuan kedua calon mempelai

2. Untuk melangsungkan perkawinan seorang yang belum mencapai umur 21 (dua puluh satu) tahun harus mendapat izin kedua orang tua.

3. Dalam hal salah seorang dari kedua orang tua telah meninggal dunia atau dalam keadaan tidak mampu menyatakan kehendaknya maka izin yang di maksud ayat (2) pasal ini cukup di peroleh dari orang tua yang masih hidup atau dari orang tua yang mampu menyatakan kehendaknya.

4. Dalam hal kedua orang tua telah meninggal dunia atau dalam keadaan tidak mampu untuk menyatakan kehendaknya, maka izin di peroleh dari wali, orang yang memelihara atau keluarga yang mempunyai hubungan darah dalam garis keturunan lurus ke atas selama mereka masih hidup dan dalam keadaan dapat menyatakan kehendaknya.

5. Dalam hal ada perbedaan pendapat antara orang-orang yang di sebut dalam ayat (2), (3),dan (4) pasal ini, atau salah seorang atau lebih di antara mereka tidak menyatakan pendapatnya, maka pengadilan dalam daerah hukum tempat tinggal orang yang akan melangsungkan perkawinan atas permintaan orang tersebut dapat member izin setelah lebih dahulu mendengar orang-orang tersebut dalam ayat (2),(3), dan (4) pasal ini.

6. Ketentuan tersebut ayat (1) sampai dengan ayat (5) pasal ini berlaku sepanjang hukum masing-masing agamanya dan kepercayaannya itu dari yang bersangkutan tidak menentukan lain. ${ }^{11}$

${ }^{10}$ Titik Triwulan Tutik, Hukum Perdata dalam Sistem Hukum Nasional, (Jakarta, Kencana, 2008), h. 111. 
Untuk memperoleh gambaran yang jelas mengenai syarat dan rukun perkawinan menurut hukum Islam sebagai berikut :

1. Calon mempelai pria, syaratnya :

a.Beragama Islam

b. Laki-laki

c.Jelas orangnya

d. Dapat memberikan persetujuan

e.Tidak terdapat halangan perkawinan

2. Calon mempelai wanita, syaratnya :

a.Beragama Islam

b. Perempuan

c.Jelas orangnya

d. Dapat di mintai persetujuannya

e.Tidak terdapat halangan perkawinan

3. Wali nikah, syaratnya :

a.Laki-laki

b. Dewasa

c.Mempunyai hak perwalian

d. Tidak terdapat halangan perwalian

Wali nikah terdiri dari 3, yakni wali nasab, wali hakim dan wali muhakkam, sebagai berikut :

1) Wali Nasab,

Adalah orang yang merupakan anggota keluarga pikah mempelai wanita yang memiliki hubungan darah patrinial, berdasarkan mahzab Syafi'I maka urutan wali nasab adalah sebagai berikut :

a) Bapak, kakek (orang tua bapak) dan seterusnya ke atas

b) Saudara laki-laki kandung sebapak seibu

c) Saudara laki-laki sebapak lain ibu

d) Keponakan laki-laki dari saudara laki-laki sebapak dan seretusnya

e) Paman, yaitu saudara dari bapak sekandung

f) Paman sebapak, yaitu saudara dari bapak sebapak lain ibu

g) Anak-anak paman kandung (saudara sepupu)

h) Anak laki-laki paman sebapak

2) Wali Hakim

${ }^{11}$ Republik Indonesia,’Undang-Undang RI Nomor 1Tahun 1974 tentang Perkawinan," dan, Kompilasi Hukum Islam (Yogyakarta: Grahamedia Press, 2014), h. 3-4. 
Apabila wali nasab tersebut tidak ada atau belum memenuhi syarat maka kuasa untuk menjadi wali nikah diberikan kepada negara dalam hal ini yang diwakili oleh menteri agama dan selanjutnya diserahkan pada petugas pencatat nikah atau yang dikenal dengan sebutan wali hakim. Biasanya petugas tersebut berasal dari kantor KUA.

3) Wali Muhakkam

Wali ini menjadi pilihan terakhir apabila wali nasab maupun wali hakim menolak bertindak sebagai wali nikah dan tidak dapat menjalankan kewajiban maupun haknya sebagai wali, dengan kata lain wali muhakkam adalah wali yang terjadi karena wali tersebut diangkat oleh pihak mempelai.

4. Saksi nikah, syaratnya :

a.Minimal dua orang laki-laki

b. Hadir dalam ijab qabul

c.Islam

d. Dewasa

5. Ijab qabul, syaratnya :

a.Adanya pernyataan mengawinkan dari wali

b. Adanya pernyataan penerimaan dari calon mempelai pria

c.Memakai kata-kata nikah, tazwij atau terjemahan dari kata nikah

d. Antara ijab dan qabul bersambungan

e.Antara ijab dan qabul jelas maksudnya

f. Orang yang terkait dengan ijab qabul tidak sedang dalam ihram haji/umrah.

g. Majelis ijab dan qabul itu harus di hadiri minimum empat orang, yaitu: calon mempelai pria atau wakilnya wali dari mempelai wanita atau wakilnya, dan dua orang saksi.

Talak (yang dapat dirujuk) itu dua kali. Suami dapat merujuk kembali istrinya setelah talak pertama dan kedua selama masa idah atau mengembalikannya sebagai istri dengan akad baru. Dalam kondisi demikian suami wajib meniatkan usaha mengembalikan istri itu sebagai tindakan yang adil demi perbaikan. Meskipun jika suami bermaksud mengakhiri perkawinan, tetap diharuskan menempuh jalan terbaik dengan tetap menghormati wanita bekas istrinya itu tanpa memperlakukannya dengan kasar. Tidak diperbolehkan bagi kalian, wahai para suami, untuk meminta kembali harta yang telah kalian serahkan kepada istri itu, kecuali apabila kalian merasa khawatir tidak mampu melaksanakan hak dan kewajiban hidup bersuami istri sebagaimana dijelaskan dan diwajibkan Allah Swt. Apabila kalian, wahai orang-orang Muslim, merasa khawatir istri-istri kalian tidak akan sanggup melaksanakan kewajiban mereka sebagai istri secara sempurna, maka mereka juga telah diberi ketetapan hukum untuk menyerahkan sejumlah harta kepada suami sebagai imbalan perceraian istri-istri itu dari suami mereka. Inilah 
adanya ketentuan hukum Allah itu, maka barang siapa melanggar atau menyalahi ketentuan itu, ia benar-benar telah berbuat zalim terhadap diri sendiri dan pada masyarakatnya. ${ }^{12}$

Perceraian dalam hukum Islam adalah sesuatu perbuatan halal yang dibenci oleh Allah swt. berdasarkan hadis Nabi Muhammad saw. sebagai berikut:

Artinya:

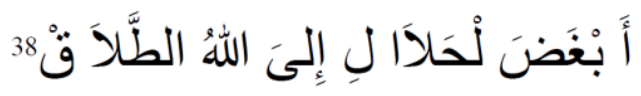

Perbuatan halal yang dibenci oleh Allah adalah talak/perceraian

Hadis di atas menjelaskan bahwa perceraian merupakan alternatif (pintu darurat) yang dapat dilalui oleh suami istri bila ikatan perkawinan tidak dapat lagi dipertahankan keutuhan dan kelanjutannya. Maksudnya adalah sudah ditempuh berbagai cara dan teknik untuk mencapai kedamaian di antara kedua belah pihak. Namun hadis di atas tidak berlaku secara mutlak. Artinya bahwa perceraian itu dibolehkan apabila terjadi masalah dalam suatu perkawinan yang sudah tidak dapat diperbaiki, bahkan perceraian bisa menjadi wajib apabila akan timbul bahaya jika perkawinan tersebut dipertahankan.

Berdasarkan bentuk-bentuk peristiwa talak tersebut di atas, maka dapat dibedakan ketetapan hukumnya yang dinamakan hukum talak. Dan hukum talak itu ada lima, yaitu ${ }^{14}$ :

\section{Talak Wajib}

Wajib hukumnya melakukan perceraian kalau konflik antara suami dan istri terus menerus terjadi dan tidak dapat dipertemukan lagi baik oleh keluarga maupun oleh Pengadilan Agama. Dan selain itu juga bagi salah satu pihak yang melakukan perbuatan kejahatan atau menjadi seorang residivis tidak perlu mempertahankan kesatuan hidup dalam keluarga, karena wajib hukumnya melakukan talak. Alasan hukumnya, ialah dalam mempertahankan kelangsungan hidup keluarga hendaknya dijalankan dengan wajar dan harmonis tanpa penyimpangan yang dapat menimbulkan akibat lain dengan merusak jiwa masing-masing. ${ }^{15}$

2. Talak Haram. vol. 1 h. 597-601

${ }^{12}$ M. Quraish Shihab, Tafsir Al-misbah Pesan Kesan dan Keserasian Al-Qur'an,

${ }^{13}$ Imam Muhammad bin Muhannad As-Syirkani, Naitul Author (Cairo: Dar al0Hadits, 1426 H/2005 M), h. 609-610

${ }^{14}$ Abdul Manan, Aneka Masalah Hukum Perdata Islam di Indonesian, Cet Ke-1, (Jakarta: Prenada Media Grup, 2006), h. 101-102

${ }^{15}$ Abdul Manan, Aneka Masalah Hukum Perdata Islam di Indonesian, Cet Ke-1, h. 101 
Diharamkan hukumnya bagi seorang suami yang menjatuhkan talak kepada istrinya tanpa sebab yang sah. Sebab yang sah itu menurut mazhab Hanafi berkenaan dengan diajukannya talak oleh suami yang tidak sehat pikirannya. Menurut mazhab Syafi'i dan mazhab Hambali suatu talak yang dijatuhkan oleh suami tidak sehat pikirannya tidak haram melainkan makruh. Hal ini berdasarkan prinsip perkawinan Islam yang tidak menghendaki kesengsaraan bagi kedua belah pihak. ${ }^{16}$

\section{Talak Mubah (boleh)}

Menceraikan istri tidak dianjurkan, tidak diwajibkan, atau tidak diharamkan asalkan sesuai dengan aturan hukum yang berlaku dan tidak menimbulkan akibat buruk bagi para pihak setelah terjadi perceraian itu. ${ }^{17}$

4. Talak Sunnat

Sunnat hukumnya menceraikan istri kalau ia tidak mau merubah kebebasan bergaulnya semasa belum kawin atau tidak mau menjaga harga diri sebagai seorang istri. $^{18}$

5. Talak Haram Ringan.

Seorang suami yang menjatuhkan talak kepada istri dalam keadaan menstruasi yang sebelumnya tidak pernah digauli termasuk talak haram ringan. Kalau talak itu dilakukan kewajiban suami merujuk atau menyatakan sebagai istrinya kembali. ${ }^{19}$

\section{METODE PENELITIAN}

1. Jenis penelitian

Jenis penelitian ini, adalah penelitian lapangan (Field Research) kualitatif deskriftif, yakni penelitian dengan cara langsung terjun ke lokasi penelitian untuk memperoleh data-data yang di perlukan. Dimana penulis akan membahas dan meneliti tentang faktor penyebeb tingginya angka Cerai Gugat serta mengetahui

\footnotetext{
${ }^{16}$ Abdul Manan, Aneka Masalah Hukum Perdata Islam di Indonesian, Cet Ke-1, h. 101

${ }^{17}$ Abdul Manan, Aneka Masalah Hukum Perdata Islam di Indonesian, Cet Ke-1, h. 102

${ }^{18}$ Abdul Manan, Aneka Masalah Hukum Perdata Islam di Indonesian, Cet Ke-1, h. 102 102

${ }^{19}$ Abdul Manan, Aneka Masalah Hukum Perdata Islam di Indonesian, Cet Ke-1, h.
} 
pertimbangan hakim dalam memutuskan perkara Cerai Gugat di Pengadilan Agama Kelas IB Polewali. Yang di maksud penelitian kualititatif adalah suatu pendekatan penelitian yang mengungkapkan situasi sosial tertentu dengan mendeskripsikan kenyataan secara benar, dibentuk oleh kata-kata berdasarkan teknik pengumpulan dan analisis data yang relevan yang diperoleh dari situasi yang alamiah. ${ }^{20}$.Bodgan dan Taylor metode kualitatif adalah prosedur penelitian yang menhasilkan data berupa kata-kata tertulis atau lisan dari orang dan prilaku yang diamati. Dalam metode ini, penelitian dilakukan oleh semacam intervensi (campur tangan) dari pihak peneliti. Intervensi ini dimaksudkan agar fenomena yang dikehendaki oleh peneliti dapat segera tampak dan diamati. ${ }^{21}$

2. Lokai Penelitian

Pada penelitian ini penulis memilih di Pengadilan Agama Polewali yang terletak di Jl. Budi Utomo No. 23 Madatte Polewali, Kabupaten Polewali Mandar, Sulawesi Barat,dengan berfokus pada faktor penyebeb tingginya angka Cerai Gugat serta pertimbangan hakim dalam memutuskan perkara Cerai Gugat di Pengadilan Agama Kelas IB Polewali

\section{Pendekatan Penelitian}

Pendekatan penelitian yang digunakan adalah pendekatan kualitatif. Data yang dikumpulkan lebih mengambil bentuk kata-kata atau gambar. Adapun hasil penelitian tertulis berisi kutipan-kutipan untuk menyediakan bukti presentasi. Datatersebut mencakup transkrip wawancara, catatan lapangan, fotografi, videotape, datapribadi, memo, dan rekaman-rekaman resmi lainnya. ${ }^{22}$

\section{Sumber Data}

Sumber data terbagi menjadi dua yaitu data primer dan data sekunder.

1. Data Primer

Data primer adalah sumber data penelitian yang diperoleh secara langsung dari sumber aslinya yang berupa wawancara, jajak pendapat dari individu atau kelompok (orang) maupun hasil observasi dari suatu obyek, kejadian atau hasil pengujian (benda). Dengan kata lain, penelitian membutuhkan pengumpulan data dengan cara menjawab pertanyaan riset (metode survei) atau penelitian benda (metode observasi). Data primer adalah data yang diperoleh langsung dari subjek

${ }^{20}$ Djam'an Satori Dan Aan Komariah, Metode Penelitian Kualitatiif, (Bandung; Alfabeta, 2009), h. 25.

${ }^{21}$ Saifuddin Azwar, Metode Penelitian, (Yogyakarta: Pustaka Pelajar, 1997), h. 21

${ }^{22}$ Emzir, Metodologi Penelitian Kualitatif Analisis Data, (Ed.1, Cet. 4; Jakarta: Rajawali Pers,2014) h, 3. 
penelitian dengan menggunakan alat pengukuran atau alat pengambilan data langsung pada subjek sebagai sumber informasi yang dicari. ${ }^{23}$

2. Data Sekunder

Data sekunder merupakan data yang berasal dari sumber kedua yang dapat diperoleh melalui buku-buku, brosur, dan artikel yang didapat dari wabsite yang berkaitan dengan penelitian ini. Data sekunder dapat diperoleh lewat pihak lain, tidak langsung diperoleh oleh peneliti dari subyek penelitiannya dan dapat pula berguna sebagai pelengkap informasi yang telah dikumpulkan sendiri oleh peneliti. Dan akhirnya data itu juga dapat juga memperkuat penemuan atau observasi yaitu teknik pengumpulan data yang dilakukan melalui suatu pengamatan, dengan disertai pencatatan-pencatatan terhadap keadaan atau perilaku objek sasaran ${ }^{24}$

\section{HASIL PENELITIAN}

\section{Data Perkara di Pengadilan Agama Polewali}

Jumlah perkara pada Pengadilan Agama Polewali tahun 2019 sebanyak 1.570 perkara, yang terdiri dari 44 perkara dari sisa tahun 2018, perkara yang diterima tahun 2019 sebanyak 1.526 perkara, sedang perkara yang diputus tahun 2019 sebanyak 1.512 perkara dan sisanya 58 perkara akan di selesaikan pada tahun 2020.kasus yang paling tinggi di tangani oleh Pengadilan Agama Polewali adalah isbat Nikah sebanyak 650 perkara, cerai gugat sebanyak 507 perkara, cerai talak sebanyak 176 perkara, dispensasi kawin sebanyak 122 perkara dan kasus lainnya.

Data perkara yang di terima dan di putus pada tahun 2019 terdiri dari :

Sisa perkara tahun 2018

$: 44$ perkara

Perkara yang di terima tahun $2019 \quad: 1.526$ perkara

Perkara yang putus

: 1.512 perkara

- Dicabut

: 65 perkara

- Ditolak

: 32 perkara

- Gugur

: 28 perkara

- Tidak diterima

: 21 perkara

- Dicoret dari register

: 14 perkara

- putus terselesaikan

perkara yang sisa tahun 2019

$: 1.352$ perkara

: 58 perkara

${ }^{23}$ Saifuddin Azwar, Metode Penelitian, h. 91

${ }^{24}$ Abdurrahmat Fathoni, Metodologi Penelitian dan Teknik Penyusunan Skripsi(Jakarta: Rineka Cipta, 2006), h.104. 
Laporan perkara yang diterima di Pengadilan Agama Polewali pada Januari sampai Desember 2019. Dari 1.526 perkara yang di terima di tahun 2019, dapat dirinci menurut jenis perkara sebagai berikut :

Tabel 4.1 Laporan perkara diterima tahun 2019

\begin{tabular}{|r|l|c|}
\hline No & Jenis Perkara & Jumlah \\
\hline 1 & Izin Poligami & 2 \\
\hline 2 & Cerai Talak & 176 \\
\hline 3 & Cerai Gugat & 507 \\
\hline 4 & Harta Bersama & 1 \\
\hline 5 & Penguasaan Anak & 1 \\
\hline 6 & Perwalian & 6 \\
\hline 7 & Isbat Nikah & 650 \\
\hline 8 & Dispensasi Kawin & 122 \\
\hline 9 & Wali Adhal & 1 \\
\hline 10 & Kewarisan & 17 \\
\hline 11 & Penetapan Ahli Waris & 38 \\
\hline 12 & Lain-lain & 5 \\
\hline & Total & $\mathbf{1 . 5 2 6}$ \\
\hline
\end{tabular}

Sumber Laporan Tahunan Pengadilan Agama Polewali

Adapun Perkara perceraian yang diteriman dan diputus/diselesaikan pada Januari sampai Desember tahun 2019, sebayak 176 perkara cerai talak yang masuk dan putus/selesai 152 perkara serta cerai gugat sebanyak 507 perkara yang masuk dan putus/selesai 474 perkara, dapat dirinci menurut perkara Cerai Talak dan Cerai Gugat pada Januari sampai Desember tahun 2019 sebagai berikut :

Tabel 4.2. Perkara perceraian masuk dan diputus/diselesaikan

\begin{tabular}{|l|l|l|}
\hline 2019 & Cerai Talak & Cerai Gugat \\
\hline
\end{tabular}




\begin{tabular}{|l|c|c|c|c|}
\hline & Masuk & Putus & Masuk & Putus \\
\hline Januari & 19 & 6 & 63 & 27 \\
\hline Februari & 16 & 15 & 47 & 30 \\
\hline Maret & 15 & 9 & 46 & 30 \\
\hline April & 13 & 10 & 56 & 33 \\
\hline Mei & 11 & 12 & 19 & 57 \\
\hline Juni & 19 & 11 & 33 & 26 \\
\hline Juli & 14 & 21 & 54 & 37 \\
\hline Agustus & 17 & 10 & 35 & 56 \\
\hline September & 19 & 14 & 53 & 33 \\
\hline Oktober & 15 & 18 & 38 & 38 \\
\hline November & 13 & 11 & 51 & 39 \\
\hline Desember & 5 & 15 & 12 & 68 \\
\hline Total & $\mathbf{1 7 6}$ & $\mathbf{1 5 2}$ & $\mathbf{5 0 7}$ & $\mathbf{4 7 4}$ \\
\hline
\end{tabular}

Sumber Laporan Tahunan Pengadilan Agama Polewali

Jumlah data dalam tabel di atas terlihat jelas bahwa jumlah perkara cerai gugat (istri yang mengajukan surat gugatan) yang masuk lebih tinggi di bandingkan jumlah perkara cerai talak (suami yang mengajukan surat gugatan perceraian),bahkan setiap bulannya mengalami peningkatanyang cukup tinggi, serta perkara putus/terselesaikan dalam perkara cerai gugat juga tinggi dibandingkaperkara cerai talak.

\section{Faktor Penyebab Tingginya Cerai Gugat di Pengadilan Agama Polewali}

Berdasarkan data perceraian Gugat di Pengadilan Agama Polewali dapat diuraikan faktor-faktor penyebab tingginya cerai gugat pada Januari sampai Desember tahun 2019, sebagai berikut :25

${ }^{25}$ Sumber berasal dari arsip data tahunan bulan Januari-Desember 2019 Pengadilan Agama Polewali 
a. Perselisihan Terus Menerus sebanyak 321 perkara, terdiri dari 46 perkara di bulan januari, 16 perkara di bulan Februari, 22 perkara di bulan Maret, 24 perkara di bulan April, 19 perkara di bulan Mei, 21 perkara di bulan Juni, 40 perkara di bulan Juli, 24 perkara di bulan Agustus, 44 perkara di bulan September, 25 perkara di bulan Oktober, 19 perkara di bulan November dan 21 perkara di Desember.

b. Meninggalkan Salah Satu Pihak sebanyak 97 perkara, terdiri dari 5 perkara di bulan Januari, 13 perkara di bulan Februari, 3 perkara di bulan Maret, 3 perkara di bulan April, 4 perkara di bulan Mei, 5 perkara di bulan Juni, 4 perkara di bulan Juli, 14 perkara di bulan Agustus, 10 perkara di bulan September, 13 perkara di bulan Oktober, 9 perkara di bulan November dan 14 perkara di Desember.

c. Ekonomi sebanyak 20 perkara, terdiri dari 2 perkara di bulan januari, 1 perkara di bulan Maret, 2 perkara di bulan April, 1 perkara di bulan Mei, 1perkara di bulan Juni, 3 perkara di bulan Agustus, 3 perkara di bulan September, 3 perkara di bula Oktober dan 4 perkara di bulan Desember.

d. KDRT sebanyak 16 perkara, terdiri dari 2 di bulan Juli, 2 perkara di bulan Agustus, 4 perkara di bulan September, 2 perkara di bulan Oktober, 1 perkara di bulan November dan 5 perkara di bulan Desember.

e. Mabuk sebanyak 8 perkara, terdiri dari 1 perkara di bulan Januari, 1 perkara di bulan Mei, 2 perkara di bulan Agustus, 3 perkara di bulan September dan 1 perkara di bulan Desember.

f. Dihukum penjara sebanyak 4 perkara, terdiri dari 1 perkara di bulan Maret, 1 perkara di bulan April dan 2 perkara di bulan Oktober.

g. Mandat sebanyak 3 perkara, terdiri dari 1 perkara di bulan Juni, 1 perkara di bulan September dan 1 perkara Oktober.

h. Murtad sebanyak 3 perkara, terdiri dari 1 perkara di bulan Februari, 1 perkara di bulan Juni dan 1 perkara di bulan November.

i. Poligami sebanyak 3 perkara, terdiri dari 1 perkara di bulan Agustus, 1 perkara di bulan September dan 1 perkara di bulan Desember.

j. Judi terdapat 1 perkara di bulan Mei.

k. Kawin Paksa 1 perkara di bulan Desember.

Jumlah keseluruhan perkara cerai gugat di Pengadilan Agama Polewali pada tahun 2019 sebanyak 507 perkara yang masuk, dengan jumlah perkara yang putus sebanyak 474 perkara, sedangkan dilihat dari faktor penyebab perkara cerai sebanyak 477 perkara, dengan terdiri dari 321 perkara karena perselisihan terus menerus, 79 perkara disebabkan meninggalkan salah satu pihak, 20 perkara disebabkan faktor ekonomi, 16 perkara karena KDRT, 5 perkara di sebabkan karena mabuk, 4 kasus karena dihukum penjara, mutrat 3 perkara, 3 perkara karena mandat, 
penyebab karena poligami 3 perkara serta penyebab karena judi dan kawin paksa masing-masing memiliki

Dari data di atas dapat dideskripsikan sebagai berikut : mendeskripsikan perkara cerai gugat dengan nomor perkara 222/Pdt.G/PA.Pwl. Penelitian ini mengakat dari sebuah kasus yang didaftarkan pada bulan Juli 2019 dan diputuskan pada bulan Agustus 2019 adapun mengenai duduk perkara dan proses persidangan kasus ini adalah sebagai berikut:

Penggugat adalah pihak perempuan (istri) bernama Raehan binti Yammadia, umur 32 tahun, bertempat tinggal di Polewali jalan kemakmuran dan bekerja sebagai ibu rumah tangga. Sedangkan tergugat adalah pihak laki-laki (suami) bernaman M. Rusli bin Lawi, umur 38 tahun bertempat tinggal di Polewali dan bekerja wiraswasta.

Berdasarkan kutipan akta nikah yang dibuat oleh pegawai pencatat nikah kantor urusan Agama kecamatan Polewali, keduanya telah menikah secararesmi pada tanggal 01 Desember 2006.Setelah melangsungkan pernikahan rumah tangga antara penggugat dan tergugat berjalan baik sebagaimana biasanya rukun dan harmonis, mereka berdua tinggal bersama di rumah kediaman orang tua penggugat kurang lebih selama 5 tahun di kelurahan Polewali di jalan Bahari, kemudian pindah kerumah kontrakan selama kurang lebih 3 tahun di kelurahan Polewali jalan Kemakmuran dan terakhir sebelum berpisah kembali bertempat tinggal di kediaman orang tua penggugat. Selama itu pula keduanya dikaruniai 2 orang anak, anak pertama berumur 12 tahun dan anak kedua berumur 3 tahun.

Namun memasuki tahun ketiga pernikahan sekitar akhir bulan Desember 2009ketentraman rumah tangga penggugat dan tergugat mulai goyah, dikarenakan alasan sering terjadi perselisihan dan pertengkaran yang disebabkan oleh: tergugat tidak dapat memberikan nafkah secara layak kepada penggugat karena hanya memberikan penghasilan sebesar Rp. 15.000- 20.000; setiap harinya dan pada saat tahun terakhir sebelum berpisah memberikan Rp. 250.000 setiap minggunya sehingga tidak dapat memenuhi kebutuhan rumah tangga dan tergugat sering mengucapkan kata-kata kasar, terlalu mengekang penggugat, dan tidak memperhatikan keluarga penggugat. Puncak dari perselisihan dan pertengkaran antara penggugat dan tergugat terjadi pada Maret tahun 2019, tergugat pamit pergi meninggalkan rumah tempat tinggal bersama kemudian pulang dan bertempat tinggal dirumah orang tua tergugat sendiri akibat dari puncak perselisihan tersebut antara penggugat dan tergugat pisah tempat tinggal selama kurang lebih 4 bulan, selama itu antara penggugat dan tergugatjarang berkomunikasi dan tergugat tidak pernah memberikan nafkah lahir maupun batin kepada penggugat.

Pada hakekatnya, penggugat masih berkeinginan untuk rukun kembali dengan tergugat namun pada akhirnya penggugat menyatakan tidak rela karena kebahagiaan dan ketentraman rumah tangga tidak dapat terwujud kembali, 
sebagaimana yang dikehendaki oleh Undang-Undang perkawinan, akhirnya penggugat berkesimpulan sudah tidak mungkin lagi dapat meneruskan hidup berumah tangga bersama tergugat dan penggugat bermaksud menggugat cerai kepada tergugat.

Selanjutnya penggugat mengajukan gugatan cerai kepada Pengadilan Agama supaya talak satu ba'in sughra yang di ucapkan oleh tergugat kepada penggugat dan penggugat mohon agar perceraian tersebut dicatatkan pada pegawai pencatat nikah.

Kemudian majelis hakim berusaha untuk mendamaikan para pihak yang berperkara melalui upaya mediasi dengan menunjuk mediator namun tetap tidak berhasil untuk mendamaikan kedua pihak tersebut hanya saja hakim mediator mendapat pernyataan bahwa si penggugat ingin bercerai sedangkan tergugat keberatan untuk bercerai, setelah mediasi gagal kemudian dibacakan surat gugatan penggugat yang mana isi gugatan tersebut tetap dipertahankan oleh penggugat.

Pada tahapan sidang berikutnya, tergugat menjawab secara lisan menyatakan tergugat tidak pernah bertengkar dengan penggugat namun akhir-akhir ini tergugat berbuat kasar hanya berupa omongan saja. Namun penggugat tetap pada pokok gugatanya yaitu bercerai dengan penggugat.Selanjutnya penggugat menguatkan dalil-dalil gugatanya dengan mengajukan alat bukti berupa fotocopy kutipan akta nikah yang dibuat oleh pegawai pencatat nikah kantor urusan Agama tertanggal 15 Desember 2010 (bukti P.1) yang bermaterai cukup dan fotocopy yang mana telah dicocokan dengan aslinya dan sesuai dengan aslinya.

Selain bukti berupa dokumen, penggugat juga menghadirkan 2 orang saksi. Saksi pertama adalah ayah kandung penggugat yang berumur 52 tahun, beragama Islam, pekerjaan swasta (sopir) dan bertempat tinggal di daerah kota Polewali. Saksi tersebut memberikan keterangan bahwa penyebab perpisahan antara penggugat dan tergugat sering terjadinya perselisihan dan pertengkaran dikarenakan tergugat telah selingkuh dengan wanita lain, saksi tersebut juga menerangkan bahwa antara penggugat dan tergugat telah pisah tempat tinggal selama kurang lebih 4 bulan. Dalam keadaan tersebut sebenarnya saksi sudah memberikan nasehat agar rukun kembali akan tetapi usaha tersebut tidak berhasil.

Saksi kedua adalah ibu kandung penggugat yang berumur 43 tahun, beragama Islam, pekerjaan ibu rumah tangga dan bertempat tinggal di aderah kota Polewali, berdasarkan dari beberapa pertanyaan yang diberikan oleh majelis hakim, saksi kedua memeberikan keterangan yang pada intinya sama dengan keterangan yang diberikan oleh saksi pertama, yaitu antara penggugat dan tergugat sering terjadi perselisihan dan pertengkaran dikarenakan tergugat telah selingkuh dengan wanita lain setelah itu antara penggugat dan tergugat telah pisah tempat tinggal selamakurang lebih 4 bulan. Dan dalam keadaan tersebut sebenarnya saksi kedua 
juga sudah memberikan nasehat agar rukun kembali akan tetapi usaha tersebut tidak berhasil.

Atas keterangan saksi-saksi tersebut, antara penggugat dan tergugat tidak menyatakan keberatan dan membenarkan keterangan saksi-saksi tersebut dan pada akhirnya penggugat menyampaikan kesimpulan untuk tetap bercerai dan tergugat menyatakan tidak keberatan bercerai dengan penggugat. Setelah itu antara penggugat dan tergugat tidak mengajukan sesuatu lagi dan mohon agar segera dijatuhkan putusan.

Berdasarkan keterangan penggugat, tergugat dan saksi-saksi dalam perkara ini, ternyata tergugat telah terbukti meninggalkan kewajibannya memberi nafkah (ekonomi) kepada penggugat dan terbukti selingkuh dengan wanita lain. Alasan tersebut menjadi faktor penyebab terjadinya perselisihan dan pertengkaran antara penggugat dan tergugat.

Dan pada akhirnya tepatnya 29 Agustus 2019 hakim menjatuhkan putusan yaitu mengabulkan gugatan penggugat dan menjatuhkan talak satu ba'in sughro tergugat terhadap penggugat.

Peneliti juga mewawancarai ibu Nurhaeni binti Alimuddin umur 48 tahun, pekerjaan Ibu Rumah Tangga, Beralamat di Jl. Bahari No 46 yang menggugat suaminya bapak Ilham bin Nahung umur 45 tahun, pekerjaan makelar mobil beralamat Dusun Kampung Baru, Desa Tonyamang dengan nomor perkara 185/pdt.G/2019/PA.Pwl. Mengugatan suaminya di bulan Maret 2019 dan putus/terselesaikan di bulan April.

Peneliti mewawancarai ibu Nurhaeni mengenai apa alasan yang melatar belakangi sehinggah menggugat suaminya?

Karena suami saya tidak memberikan uang belanja, dia memegan uangnya sendiri, siapa perempuan yang bisa tenang kalau tidak dikasi uang belanja..? dia juga tidak bisa menghargai keluarga saya. Karena faktor ekonomi kami sering bertengkar.

Selanjutnya ibu Nurhaneni menambahkan

Bahwa mereka telah pisah tempat tinggal selama 2 tahun, dan suami saya sudah menikah lagi dengan perempuan lain tanpa seizin saya, dan mereka sudah memiliki 1 anak.

Lebih lanjut peneliti bertanya kembali ke ibu Nurhaeni tentang bagaimana proses persidangan?

Suami saya tidak pernah datang ke pengadilan bahkan telah di panggil secara resmi, maka hasil putusan persidangan saya itu putusan Verstek.Dengan saksi dari adik kandung saya dan ipar saya,Maka di bulan April keluar surat Akta Cerai.

Demikian ibu Nurhaeni menambahkan tentang bagaimana hubungan dengan mantan suami? 
Setelah bercerai hubungan saya dengan mantan suami tetap menjalin komunikasi semata-mata hanya untuk anak. Mantan suami masih tetap menafkahi anaknya. ${ }^{26}$

Dari wawancara dengan ibu Nurhaeni dapat di simpulkan bahwa faktor penyebab beliau menggugat suaminya karena faktor ekonomi yang menyebabkan terjadinya perselisihan dan pertengkaran terus menerus seminggah terpisah tempat tinggal selama 2 tahun dan sang suami telah menikiah lagi tanpa seizing beliau, dan merasa bahwa rumah tangganya memang sudah tidak ada harapan lagi untuk di pertahanka dan ingin menyelesaikan rumah tangganya memalaui prosedur persidangan.

\section{Pertimbangan Hakimdalam Menyelesaikan Perkara Cerai Gugatdi Pengadilan Agama Polewali}

Pertimbangan hakim dalam menyelesaikan perkara cerai gugat maupun cerai talak hampir sama menimbang bahwa maksud dan tujuan penggugat untuk menyelesaikan permasalahan dalam rumah tangganya menurut prosedur Pengadilan dan tentunya berlandaskan dengan dasar-dasar hukum yang berlaku.Untuk lebih jelasnya peneliti melakukan wawancara dengan orang-orang yang dirasa dapat membantu menyelesaikan skripsi ini.

Seperti yang diungkapkan oleh pegawai Pengadilan Agama Polewali, Bapak Abdul Rahim, S.Ag,

Perceraian menurut saya adalah salah satu jalan keluar apabila rumah tangga terus menerus terjadi perselisihan dan percekcokan apalagi dalam waktu yang cukup lama seperti kebanyakan kasus yang di terima di Pengadilan, percekcokan dalam waktu yang lama bahkan ada beberapa yang sudah tidak serumah lagi dengan pasangannya. ${ }^{27}$

Hal lain diungkapkan oleh Bapak Muh. Irwan, seorang masyarakat dan juga Guru, sebagai berikut:

Perceraian terjadi karena orang kurang mengerti dengan hak dankewajiban sebagai suami isteri. Perceraian juga bisa terjadi karena kurangnya iman dan ambisi yang kuat, mengerti agama itu sangat penting.Kalau orang sudah mengerti dengan masalah agama maka akan dapat menyelesaikan permasalahan yang ada dalam rumah tangga. Lebih baik memperbaiki kesalahan-kesalahan yang ada daripada memiliki pasangan baru yang bukan berarti masalah dalam rumah tangga tidak muncul lagi bukan?. Permasalahan perkawinan juga dapat disebabkan karena orang orang tidak mengerti benar

\footnotetext{
${ }^{26}$ Nurhaeni, penggugat (istri), wawancara oleh penulis di jalan Bahari No. 46 polewali 20 Juni 2020

${ }^{27}$ Abdul Rahman, Pegawai Pengadilan, wawancara oleh penulis di Pegadilan Agama Polewali 4 Mei 2020
} 
bagaimana memilih teman hidup, seperti : Akhlaknya bagaimana, seagama atau tidak, beriman atau tidak, anak siapa yang menyangkut bobot, bibit, dan bebetnya, dan dunianya dalam arti bekerja atau tidak, berpendidikan atau tidak. Kalau beberapa aspek tersebut disaring dengan benar maka Insya Allah permasalahan dalam perkawinan dapat terselesaikan tanpa menyinggung tentang perceraian. ${ }^{28}$

Pandangan dari masyarakat ini dapat disimpulkan kurang setuju dengan perceraian sebagai jalan keluar dari permasalahan rumah tangga. Perceraian terjadi karena orang kurang mengerti dengan hak dan kewajiban masing-masing, dan karena lemahnya iman. Untuk itu Agama sangatlah penting untuk dimengerti agar dapat menyelesaikan masalah dalam rumah tangga.

peneliti melakukan wawancara dengan ibu Ferawati Waris, S.Ag. selaku pegawai di Pengadilan Agamadi bagian pendaftaran perkara mengenai bagaimana prosedur pendaftaran perceraian?

Istri mendaftarkan perkaranya di Pengadilan Agama dilengkapi surat gugatanserta berkas-berkas penungjang lainnya dengan membayar biaya administrasi.Setelah pengugat melakukan pendaftaran maka pihak pengadilan memeriksa berkas perkara pengugat serta penunjukan Hajelis Hakim yang bertanggung jawab atas perkara tersebutdi tentukan Ketua Pengadilan Agama

Selanjurnya peneliti bertanya lagi ke ibu Ferawati Waris, S.Ag.bagaimana tatacara perceraian gugat? "Pihak Pengadilan mengubungi penggugat tentang jadwal persidagan serta menyurat ke tergugat perhal surat gugatan dan jadwal persidangan". ${ }^{29}$

Selanjutnya peneliti melakukan wawancaradengan ibu $\mathrm{Hj}$. Nailah B, M.H selaku hakim tentang tatacara peceraian gugat? "Apabila penggugat (istri) dan tergugat (suami) menghadiri sidang pertama maka Majelis Hakim menyarankan perdamaian melaui jalur Mediasi". ${ }^{30}$

Dari hasil wawancara di atas bahwa setelah jadwal persidangan tentukan pihak Pengadilan dan memanggil yang berperkara, jika di persidangan pertama pengugat dan tergugat menghadiri persidangan Majelesi hakim menasehati penggugat agarbisa berdamai dengan tergugat melalui jalur Mediasi sesuai dengan Perma Nomor 1 Tahun 2006 tentang Prosedur Mediasi di Pengadilan, dan menunda persidangan untuk memberi kesempatan kepada penggugat dan tergugat menempuh

${ }^{28}$ Huh. Irwan, Masyarakat dan Guru, wawancara oleh penulis di jalan Kemakmuran Polewali 20 Juni 2020

${ }^{29}$ Ferawati Waris, Pegawai Pengadilan, wawancara oleh penulis di Pegadilan Agama Polewali 12 Mei 2020.

${ }^{30}$ Nailah B, Hakim Pengadilan, wawancara oleh penulis di Pengadilan Agama Polewali 12 Mei 2020.s 
proses Mediasi yang di tangani oleh Hakim Mediator yang bisa di tunjuk oleh ke dua belah pihak atau di tunjuk oleh Ketua pengadilan di luar Majelis Hakim dan hakim anggota yang bertanggung jawab atas perkara tersebut, jika melalui jalur Mediasi penggugat dan tergugat dapat berdamai maka akan dibuatkan akta perdamaian dan penggugat mencabut gugatannya, namun apa bila penggugat masih bersikeras dengan keinginannya maka persidangan akan di lanjutkan dengan jadwal persidangan selanjutnya, namun jalur perdamain melalui Mediasi ini hanya bisa berjalan ketika penggugat dan tergugat menghadiri persidangan.

Peneliti juga melakukan wawancara dengan bapak Ir. Rasyid Ridha Syahide, S.H.selaku hakim bagimana jika tergugat tidak menghadiri persidangan?

Apabila dalam persidangan tergugat tidak menghadiri persidangan setelah dipanggil secara patut oleh Pengadilan makan putusanpersidagan tersebut bersifatVerstek. ${ }^{31}$

Selanjutnya di pertegas oleh bapak Drs. H. Abd Jabbar, M.H. selaku hakim di Pengadilan Agama

ketika tergugat tidak menghadiri persidangan maka persidagan tetap bisa berlanjut dan Majelis Hakim tetap menyarankan untuk melalukan perdamaian di setiap persidangan. ${ }^{32}$

Dari hasil wawancara di atas bahwa walaupun pihak tergugat tidak menghadiri persidangan walaupun telah di panggil secara resmi, maka persidangan akan tetap di lanjutkan dan hasil putusan persidangan tersebut di namankan putusan Verstek.

Peneliti melakukan wawancara dengan ibu Hj. Nailah B, M.H. selaku Hakim, bagaimana persidangan berlangsung ketika kedua belah pihak menghadiri persidangan?

Jika Mediasi tidak berhasil, disidang selanjutnya Majelis hakim dalam persidanganmemeriksa berkas perkara dan meneliti bukti-bukti dengan tanya jawab dengan penggugat dan tergugat lalu dihubungkan dengan keterangan parah saksi yang disiapkan penggugat 2 orang dewasa yang di ambil sumpahnya. ${ }^{33}$

\footnotetext{
${ }^{31}$ Rasyid Ridha Syahide, Hakim Pengadilan, wawancara oleh penulis, Pengadilan Agama Polewali 20 Mei 2020

${ }^{32}$ Abd Jabbar, Hakim Pengadilan, wawancara oleh penulis, Pengadilan Agama Polewali 20 Mei 2020

${ }^{33}$ Nailah B, Hakim Pengadilan, wawancara oleh penulis, Pengadilan Agama Polewali 20 Mei 2020.
} 
Saksi berjumlah 2 orang di sediakan oleh pengugat yang merupakan keluarga atau orang-orangdekat dengan penggugat dan tergugat seperti ibu, bapak, saudara, bibi, paman, tetangga yang memiliki hubungan dengan penggugat dan tergugat selama melangsungkan pernikahan, yang tentunya kesaksiannya sesuai dengan yang tertulis di dalam surat gugatadiawali dengan pengambilan sumpah saksiakan berkata jujur dan tidak akan berbohong di depan persidangan.

Lebih lanjut peneliti melakukan wawancara dengan $\mathrm{Hj}$. Nailah B, M.H. selaku hakim, bagimana pertimbagan hakim dalam menyelesaikan perkara cerai gugat?

Perkara perceraian apa saja kalaumasalah pertimbangannya berdasarkan keterangan saksi, terbukti tidak? keterangan saksi memberikan keterangan sesusai dengan yang menjadi alasan-alasan gugatannya maksudnya di lihat langsung, di alami langsung itu namnya terbukti, kalua di dengar atau mendengarkan cerita itu namanya testimoni, itu baru bukti awal dan di perlukan bukti lain. ${ }^{34}$

Demikian bapak Drs. H. Abd Jabbar, M.H. selaku hakim menambahkan mengenai bagaimana pertimbagan hakim dalam menyelesiakna perkara cerai gugat

Majelis hakim telah menemukan faktah bahwa rumah tangga pengugat dan tergugat telah pecah, dan ditambahdengan pertimbangan-pertimbagan lain seperti sudah lama pisah tempat tinggal, ada gangguan pihak lain (WIL), maka Majelis Hakim mengambil putusan mengabulkan gugatan pengugat dengan menceraikan pengugat dan tergugat. ${ }^{35}$

Menimbang bahwa penggugat mengajukan gugatan cerai dengan alasanalasan perceraianyang terdapat dalam pasal 116 Kompilasi Hukum Islam dan pasal 19 Peraturan Pemerintah No 9 Tahun 1975. Maka mempertahankan rumah tangga yang sudah tidak ada kecocokan antar penggugat dan tergugat akan menimbulkan penderitaan lahir dan batin di kedua belahpihak, sehinggah perceraian merupakan alternatif yang sudah tepat dan benar walau perceraian itu adalah perbuatan halal yang dibenci Allah SWT.

Lebih lanjut peneliti melakukan wawancara dengan ibuHj. Nailah B, M.H. selaku hakim, bagiamana jika tergugat keberatan dengan keputusan hakim?

Jika putusannya bersifat Verstek maka tergugat mengajukan perlawananVerzet dasar hukum Pasal 149 RBg,dengannomor perkara yang sama, jika putusanya

\footnotetext{
${ }^{34}$ Nailah B, Hakim Pengadilan, wawancara oleh penulis, Pengadilan Agama Polewali 20 Mei 2020.

${ }^{35}$ Abd Jabbar, Hakim Pengadilan, wawancara oleh penulis, Pengadilan Agama Polewali 20 Mei 2020.
} 
merupakan putusan biasa (pengugat tergugat menghadiri persidangan) maka tergugat bisa mengajukan banding." 36

Dipertegas oleh bapak Ir. Rasyid Ridha Syahide, S.H. selaku hakim dengan pertanyaan yang sama mengenai bagaimana jika tergugat keberatan dengan keputusn hakim?

Setelah pembacaan putusan hakim, tergugat memiliki tenggang waktu selama14 hari untuk mengajukan upaya hukum jika keberatan dengan keputusan hakim, adapun upaya hukumnya banding, jika masih keberatan lanjut Kasasi di mahkama Agung, jika masih keberatan lanjut di Peninjauan $\mathrm{Kembali}^{37}$

Adapun upaya hukum yang dapat di lakukan tergugat bisa melalui tahapan upaya hukum yaitu:

a. Upaya hukum biasa

1) Perlawana/verzet

Adalah upayah hukum terhadap putusan di luar hadirnya tergugat (putusan Verstek) dasar hukum verzet dalam pasal 129 HIR. Dan di laksanakan di Pengadilan

2) Banding

Adalah upaya hukum dilakukan apabila salah satu pihak tidak puas terhadap putusan pengadilan. Dasar hukumnya UU No. 4 Tahun 2004 tentang perubahan atas UU No. 20 Tahun 1947 tentang Peradilan Ulangan, dilaksanakan di Pengadilan Tinggi.

3) Kasasi

Putusan yang di ajukan dalam putusan kasasi adalan putusn banding. Dalam pasal 30 UU No. 14 Tahun 1985 jo. UU No. 5 Tahun 2004. Di Mahkama Agung. b. upaya hukum luar biasa

1) Peninjauan kembali (request civil)

Merupakansuatu upaya agar putusan pengadilan baik tinggkat Pengadilan maupu Pengadila Tinggi, mupun Mahkama Agung. Peninjauan kembali dalam Pasal 15 UU No. 19 Tahun 1964 dan Pasal 31 UU No. 13 Tahun 1965

2) Perlawanan pihak ke tiga (denderverzet)

Merupakan salah satu upaya hukum luar biasa yang dilakukan oleh pihak ketiga dalam suatu perkara perdata, pihak ketiga yang bukan pihak dalam perkara yang bersangtkutan, karena merasa dirugikan.

${ }^{36}$ Nailah B, Hakim Pengadilan, wawancara oleh penulis, Pengadilan Agama Polewali 20 Mei 2020.

${ }^{37}$ Rasyid Ridha Syahide, Hakim Pengadilan, wawancara oleh penulis, Pengadilan Agama Polewali 20 Mei 2020 
Lebih lanjut peneliti melakukan wawancara dengan ibu Hj. Nailah B, M.H. selaku hakim,apa dasarhukum yang digunakan dalam memutuskan perkara perceraian?

Mengacu pada Undang-Undang Nomor 7 Tahun 1989 Tentang Peradilan Agama, Kompilasi Hukum Islam, UU Nomor 1 Tentang Perkawinan, Peraturan Pemerintah No 9 Tahun 1975. ${ }^{38}$

Demikian bapak Ir. Rasyid Ridha Syahide, S.H. menambahkan mengenai dasar hukum yang di pakai dalam putusan perkara cerai gugat? "Dasar hukum di pakai jika ada anak yaitu UU Perlindungan Anak, Kitap Undang-Undang Hukum Perdata"39

Lebih lanjut peneliti melakukan wawancara dengan bapak Drs. H. Abd Jabbar, M.H. selaku hakim, mengenai faktor perceraian paling tinggi ditangani di Pengadilan Agama?

Sebenarnya kalau mengenai alasan bercerai, orang yang ingin bercerai di pengadilan bukan hanya satu alasan tapi bayak alasan-alasan yang saling berkaitan, seperti kasus selalu bertengkar dalam rumah tangga, salah satu pihak meninggalkan, faktor ekonomi, bahkan KDRT..$^{40}$

Selanjutnya peneliti melakukan wawancara degan ibu Hj. Nailah B, M.H. selaku hakim, apa akibat yang di timbulkan dari perceraian?

Tentunya perceraian dari kasus cerai gugat yaitu tugas mencari nafkah jatuh ke istri, dampaknya juga dapat dirasakan oleh anak yang kehilagan kasi sayang dari ke dua orang tuanya. ${ }^{41}$

Selanjutnya Wawancara dengan bapak Abdul Rahman, S.Ag selaku pegawai di Pendailan Agama, mengenai bagaimana tatacara penerbitan Akta Cerai?

Setelah putusan hakim di bacakan selama tenggang waktu 14 hari tapi baik dari pihak tergugat maupun penggugat, tidak mengambil upaya hukum terhadap putusan hakim, makan akan di terbitkan akta cerai. ${ }^{42}$

38 Nailah B, Hakim Pengadilan, wawancara oleh penulis, Pengadilan Agama Polewali 20 Mei 2020.

${ }^{39}$ Rasyid Ridha Syahide, Hakim Pengadilan, wawancara oleh penulis, Pengadilan Agama Polewali 20 Mei 2020

${ }^{40}$ Abd Jabbar, Hakim Pengadilan, wawancara oleh penulis, Pengadilan Agama Polewali 20 Mei 2020.

${ }^{41}$ Nailah B, Hakim Pengadilan, wawancara oleh penulis, Pengadilan Agama Polewali 20 Mei 2020.

${ }^{42}$ Abdul Rahman, Pegawai Pengadilan, wawancara oleh penulis di Pegadilan Agama Polewali 4 Mei 2020 
Dari data yang di dapatkan peneliti di Pengadilan Agama dan dari hasil wawancara dengan narasumber, bahwa di zaman sekarang bukan hanya suami memiliki hak untuk menceraikan istri tetapi istri pun memiliki hak yang sama untuk mengugat suaminya, di dalam peradilan untuk membedakan antara pihak yang mengajukan perceraian yaitu cerai gugat istri yang mengajukan, sedangkan cerai talak suami yang mengajukan.Pecerian melalui prosedur pengadilan baik itu cerai gugat maupun cerai talak harus melalui prosedur yang telah di tentukan oleh Undang-undang, serta terpenuhinya alasan-alasan perceraian yangterdapat dalam Komplikasi Hukum Islam dan pasal 19 Peratutran Pemerintah No 9 tahun 1975. Karena jika mempertahankan rumah tangga yang tidak bisa hidup harmonis dan bahagia yang akan menimbulkan penderitaan lahir batin baik dari salah satu pihak atau pun ke duanya,walaupun perceraian merupakan perbuatan yang halal dibenci oleh allah.

Peceraian merupakan jalan terakhir yang di tempuh setelah melalui berbagai macam cara perdamaian namun tidak berhasil baik itu dari pihak keluarga, Jika perceraian melalui prosedur persidangan, akan ada hakim yang menegahi istri dan suami untuk mendamaikan dalam prosedur Mediasi, dan tidak langsung mengabulkan gugatan pengugat, hakim harus mempertimbangkan alasanalasanuntuk bercerai, apakah sudah sesuai dengan yang ada dalam Undang-undang yang berlaku, dan telah mengupayahkan mendamaikan kedua belah pihak, serta melihat dari keterangan saksi yang sesuai dengan isi gugatan yang sediakan oleh pengugat di hadapan persidanga, setelah hakim telah menemukan fakta-fakta bahwa rumah tangga tersebut memang sudah mengalami keretakan dan sudah tidak bisa dipertahankan dan hidup rukun serta akan menimbulkan penderitaan lahir batin maka hakim berkewajiban menjatuhkan putusan mengabulkan permohonan pengugat.

Dari data yang di dapatkan peneliti di Pengadilan Agama bahwa kasus cerai gugat isti yang mengugat pada tahun 2019 jauh lebih tinggi dibandingkan dengan kasus cerai talak suami yang mengugat di tahun yang sama bahkan mengalami peningkatan di setiap bulannya, adapun fakto-faktor yang mempengaruhi tingginya angka cerai gugat di Pengadilan Agama yaitu, di sebabkan kurangnya pemahaman agama seperti Perselisihan Terus Menerus, Judi Mabuk, Mandat, Dihukum Penjara, KDRT, Murtad, dengan faktor lain yang mempengaruhi perceraian gugat seperti, Meninggalkan Salah Satu Pihak, Poligami, Kawin Paksa dan faktor Ekonomi. Fakto-faktor tersebut sudah memenuhi syarat dalam Islam dan Undang-undang untuk bercerai. 


\section{PENUTUP}

\section{A.Kesimpulan}

Berdasarkan hasil penelitian tentang "Analisis Terhadap Faktor Tingginya Angka Cerai Gugat di Pengadilan Agama Polewali Tahun 2019" tentunya di Kantor Pemgadilan Agama Polewali terletak di J1. Budi Utomo No. 23, Polewali, Sulawesi Barat

1. faktor penyebab tingginya cerai gugat yang terjadi di Pengadilan Agama Polewali tahun 2019 antara lain: (1) Perselisihan Terus, (2) Meninggalkan Salah Satu Pihak (3) Ekonomi, selanjutnya terdapat pula faktor-faktor lain yang menyebabkan cerai gugat antara lain : KDRT, Mabuk, Dihukum Penjara, Mandat, Poligami, Murtad, Judi, Kawin Paksa. Dari semua faktor penyebab perceraian di atas bahwa peneliti menyimpulkan bawah semua faktor terjadi di karenakan kurangnya pemahaman agama sehinggah lalainya terhadap tanggung jawab dalam berumah tanggah sehinggah menimbulkan penyebab perceraian.

2. Pertimbagan hakim dalam memutuskan perkara cerai gugat (1) bahwa Majelis Hakim telah berupaya mendamaikan penggugat dan tergugat melalui sidang mediasi (ketika penggugat dan tergugat menghadiri persidangan) dan disetiap persidangan, akan tetapi penggugat tetap dalam pendirian untuk menyelesaikan permasalahan rumah tangganya menurut persedur Pengadilan, (2) bahwa penggugat dan tergugat sudah tidak bisa di satukan kembali menjadi sepasang suami istri dan jika dipertahankan akan menimbulkan penderitaan lahir batin dari kedua belah pihak, (3) dengan terpenuhinya alasan-alasan untuk bercerai dalam pasal 116 Kompilasi Hukum Islam dan pasal 19 Peraturan Pemerintah No 9 Tahun 1975.

Sistem pemungutan pajak restoran yang ada di Badan Pendapatan Kab. Polewali Mandar yakni ada dua yaitu secara manual dan melalui alat MPOS (Machine Payment Online System). Praktek pemungutannya yaitu petugas lapangan Badan Pendapatan khususnya di Bidang Pajak Restoran melakukan penyampaian SPTPD, SKPD, serta penagihan terhadap wajib pajak setiap bulan. Yang membedakan dalam hal sistem pemungutan yang menggunakan alat MPOS dan tidak menggunakan alat MPOS itu terletak pada besar penentuan jumlah pajak terutangnya. Untuk objek pajak yang menggunakan MPOS itu jumlah pajaknya terhitung berdasarkan hasil transaksi yang sudah dia input pada alat tersebut sehingga yang menuliskan jumlah pajak terutang pada SPTPD itu dari pihak Badan Pendapatan. Sedangkan yang tidak menggunakan alat MPOS yaitu wajib pajak yang melaporkan omzet dan menuliskan sendiri jumlah pajak terutang pada SPTPD pada 
saat penyampaian. Adapun penyetorannya melalui rekening Kasda baik secara langsung maupun transfer.

Sistem pajak restoran yang menggunakan 2 sistem berbeda dalam konteks hukum ekonomi Islam dibolehkan karena kedua sistem tersebut sama-sama memberi manfaat namun adanya penggunaan alat MPOS itu lebih banyak memberi manfaat daripada sistem manual. Tujuan pemasangan alat MPOS semata-mata karena kemaslahatan bersama sebagaimana disebutkan dalam kaidah ushul fiqh yang mengatakan bahwa"menolak kerusakan (Mudharat) diutamakan ketimbang mengambil manfaat (Maslahah)." Sebagai warga negara kita sudah semestinya membantu pemerintah tentunya dengan menjalankan kewajiban membayar pajak. Dalam QS. An-Nisa ayat 59 juga dijelaskan tentang perintah untuk mengikuti pemimpin dan ulama selama tidak bertentangan dengan syariat Islam.

\section{B.Saran}

Adapun saran yang diajukan peneliti sebagai berikut:

1. Kepada pihak Badan Pendapatan Kab. Polewali Mandar sebaiknya meningkatkan pengawasan terhadap wajib pajak yang tidak menggunakan alat MPOS.

2. Membangun hubungan yang baik antara pihak Badan Pendapatan Kab. Polewali Mandar dengan wajib pajak.

3. Kepada pihak Badan Pendapatan Kab. Polewali Mandar agar secepatnya mengadakan pemerataan penggunaan alat MPOS. 


\section{DAFTAR PUSTAKA}

Arto, A. Mukti, Praktek Perkara Perdata pada Pengadilan Agama, Yogyakarta: Pustaka Pelajar, 1998.

Azwar Saifuddin, Metode Penelitian, :Yogyakarta: Pustaka Pelajar, 1997

Djam'an Satori Dan Aan Komariah, Metode Penelitian Kualitatiif, :Bandung;

Alfabeta, 2009

Departemen Agama RI, Al-Quran dan Terjemahannya, Surabaya: 2014

Emzir, Metodologi Penelitian Kualitatif Analisis Data, Ed.1, Cet. 4; Jakarta: Rajawali Pers, 2014

Fathoni Abdurrahmat, Metodologi Penelitian dan Teknik Penyusunan Skripsi :Jakarta:

\section{Rineka Cipta, 2006}

Kompilasi Hukum Islam

Manan, Abdul, Aneka Masalah Hukum Perdata Islam di Imdonesian, Cetakan Pertama, Prenada Media Grup, Jakarta, 2006

Muhammad, Imam bin Muhannad As-Syirkani, Naitul Author Cairo: Dar al- Hadits, $1426 \mathrm{H} / 2005 \mathrm{M}$

Rahman, Abdul Ghozali, Fiqh Munakaha, Jakarta: Prenada Media Group, 2003

Republik Indonesia, Undang-Undang RI Nomor 1Tahun 1974 tentang Perkawinan dan Kompilasi Hukum Islam, Yogyakarta: Grahamedia Press,2014

Rofiq, Ahmad, hukum islam Indonesia, Jakarta PT, Raja Garfindo Persada, 2003

Sabiq, Sayyid, Fiqih Sunnah Jilid VI, Bandung:Al-Maarif, 1990

Sabiq, Sayyid, Fiqih al-Sunnah Jilid II, Beirut: Dar Al-Fikr, 1983

Shomad, Abd., Hukum Islam Penormaan Prinsip Syariah dalam Hukum Indonesia, Jakarta, kencana 2010

Tutik, Titik triwulan, Hukum Perdata dalam Sistem Hukum Nasional, Jakarta, Kencana , 2008

Undang-Undang No. 1 Tahun 1974 tentang Perkawina

Undang-Undang Republik Indonesia Nomor 1 Tahun 1974 Tentang Perkawinan dan Kompilasi Hukum Islam,

Quraish M. Shihab, “Tafsir Al-misbah Pesan Kesan DAN Keserasian Al-Qur’aN 
